\title{
La persecución en el cristianismo primitivo*
}

\author{
Rafael Aguirre, \\ Universidad de Deusto, Bilbao, \\ Centro de Reflexión Teológica, San Salvador.
}

Quisiera comenzar estas reflexiones con unas palabras personales. El presente artículo me ha llevado al estudio de los textos bíblicos, a lecturas, acopio de datos y reflexión, pero la motivación última de todo ello ha sido el recuerdo estimulante de los mártires de nuestros días. El martirio de la comunidad de jesuitas de San Salvador, de cuya hospitalidad y amistad había disfrutado durante unos inolvidables meses de 1987, durante mi estancia como profesor en la UCA, me hizo descubrir las potencialidades latentes e insólitas de los acontecimientos que están en el origen de la historia cristiana.

En el estudio del pasado he querido ser fiel al rigor histórico, pero también quisiera invitar al lector a hacer presente y productivo ese pasado, y a desarrollar sus mejores posibilidades. Si la historia se usa para reivindicar a los mártires del pasado en favor de nuestras propias causas, hacemos un mal uso de ella, pero la usamos bien si descubrimos lo que las causas de aquellos mártires exigen de nosotros en el presente. Un culto a los perseguidos y a los mártires, que sirva para justificar en su nombre la historia de poder $\longrightarrow$ de claudicación ante el poder- de un sistema religioso, es malo, pero es bueno asumir la causa de los perseguidos y mártires de nuestros días.

Desde esta perspectiva, este artículo quiere ser un homenaje a todos los mártires salvadoreños, representados por mis amigos jesuitas, que han re-escrito la historia del primer mártir, Jesús de Nazaret, con su entrega a los hermanos y hermanas hasta la muerte

* Este artículo es una ponencia pronunciada por el autor en el I Congreso Trinitario $F e$, cautivero y liberación, celebrado en Granada, del 6 al 8 de octubre de 1995. 


\section{De la persecución de Jesús a la persecución de los cristianos}

La persecución es un tema central en el cristianismo primitivo, tanto histórica como teológicamente. Todos los documentos del Nuevo Testamento hablan de la persecución de los cristianos y tienen su foco en un perseguido hasta el martirio, Jesús, el mesías crucificado.

El tema nos lleva, sin duda, al corazón de la historia y de la vida cristiana. Pero su misma riqueza y amplitud amenazan con desbordarnos y perdernos: malo e imposible sería intentar abarcarlo todo, pero cualquier selección es también una pobreza y puede resultar injusta. Espero acertar con un enfoque que haga justicia a la realidad del cristianismo primitivo y sea útil en un congreso como el que nos reúne estos días.

Mi estudio se va a limitar al Nuevo Testamento y debe comenzar precisando los términos. En efecto, "la persecución" se manifiesta de formas muy diferentes en la historia de la Iglesia. En nuestros días hemos visto persecuciones en América Latina, en países islámicos, en los regímenes del socialismo real, que tenían características muy distintas y merecen valoraciones teológicas muy diversas. Así, sería un error pensar que la primera persecución contra los cristianos fue iniciativa de las autoridades imperiales que los detenían en virtud de leyes específicas, los llevaban ante los tribunales y, eventualmente, al martirio. Las persecuciones así entendidas son, más bien, un fenómeno relativamente tardío.

En el Nuevo Testamento nos encontramos con persecuciones muy reales, pero que hay que entender en un sentido más amplio: los creyentes son hostigados en su círculo familiar o por su ambiente social, expulsados de las sinagogas, calumniados de mil formas, acusados ante tribunales diversos y, a veces, condenados a la muertel.

En las comunidades primitivas se afrontan de maneras distintas estas persecuciones, lo que depende no sólo de su gravedad, sino también de las distintas maneras como se entendían las relaciones con el mundo2. El pluralismo del

1. K. Kertelge, "Heureux ceux qui souffrent persécution pour la justice (Mt 5, 10)", Communio, marzo-abril 1987, p. 9: la violencia que sufrían los primeros cristianos no eran persecuciones organizadas sistemáticamente, sino acciones esporádicas debidas a diversas causas; así se explican también los acosos contra los cristianos de Nerón y Domiciano. L. Thompson, "A Sociological Analysis Of Tribulation In The Apocalypse Of John", Semeia, 36, 1986: "Términos como 'opresión', 'tribulación' o 'persecución' pueden ser usados para identificar situaciones sociales que contienen diferentes ingredientes o lo mismos ingredientes pero en proporciones diversas" ( $\mathrm{p}$. 170).

2. Ya en el judaísmo cercano al siglo I hay actitudes muy distintas a la hora de relacionarse con la sociedad helenista, desde un judaísmo helenista y abierto a un cierto sincretismo hasta la línea de los Macabeos y de la apocalíptica de oposición 
cristianismo primitivo, tan subrayado por la investigación actual, se pone de manifiesto también ante la persecución.

La fe cristiana, por su naturaleza misma, liene siempre latente un potencial de conflicto con el mundo, y la razón se encuentra en la historia que está en su punto de partida: la vida de Jesús de Nazarel y su muerte en la cruz.. Explícitamente lo anuncia Jesús: "acuérdense de las palabras que les he dicho: el siervo no es más que su Señor. Si a mí me han perseguido, también les perseguirán a ustedes" (Jn 15, 20).

La crucifixión de Jesús, en efecto, no fue produclo de un malentendido, ni consecuencia de una necesidad metafísica, ni advino de forma sorprendente. Fue el desenlace verosímil del estilo de vida de Jesús y del conflicto que introdujo.

Precisamente uno de los objetivos centrales de los evangelios es reivindicar la vida concrcla del Jesús terrestre para mostrar así la centralidad de la cruz a una Iglesia que muy pronto tuvo la tentación de olvidarse de las implicaciones históricas de ella y de sus exigencias. Y es que es muy distinto tener como punto de referencia histórica una utopía o una experiencia socialmente triunfadora, por ejemplo el Estado de La Meca instaurado por Mahoma, que la vida de un crucificado.

Los evangelios presentan la persecución y el martirio de Jesús polémicamente ante una Iglesia a la que le cuesta entenderlo, y lo presentan además como paradigma de la vida cristiana. Es obvio que no es posible hacer ahora un estudio histórico de la persecución, del conflicto y de la muerte de Jesús. El evangelio de Mateo es el que más utiliza la terminología de la persecución ${ }^{3}$ y de la huída de Jesús ante las asechanzas de sus enemigos ${ }^{4}$. Desde su infancia Jesús es perseguido por los reyes herodianos y por las autoridades judías y tiene que huir primero a Egipto $(2,13)$ y después a Nazaret $(2,22-23)$. Ya adulto, cuando se entera del apresamiento del Bautista, escapa a Galilea (4, 12). Vuelve a huir porque los fariseos quieren matarlo $(12,14-15)$ y más tarde se va a un lugar desierto cuando se entera de que Herodes ha matado a Juan Bautista $(14,13)$. Tras una fuerte polémica con escribas y fariseos huye hacia territorio pagano $(15,21 ;$ cfr. 16, 4).

Los evangelios, pues, no sólo intentan dar una explicación teológica de la muerte de Jesús, sino también una explicación histórica de la cruz. La vida de Jesús está atravesada por el conflicto y la persecución.

frontal. De alguna manera a estas actitudes tienen su prolongación entre los cristianos. Cfr. W. H. C. Frend, Martyrdom and Persecusion in the Early Church, New York, 1967, pp. 22-58.

3. Dioko. $7 / 0 / 3 / 2 / 9$.

4. Anajoreo. $10 / 2 / 0 / 1 / 2$. 
El evangelio de Juan, en un texto muy teológico, pero que probablemente conserva una valiosa tradicion histórica, nos cuenta que las autoridades judías, preocupadas por la resonancia popular de Jesús, dan al final y en Jerusalén una requisitoria para detenerlo $(11,53.57)$, ante lo cual éste se retiró con sus discípulos a una ciudad, Efraín, que linda con el desierto5.

Jesús es un mártir, porque su muerte es consecuencia de su vida; y Jesús no se derrumba ante su muerte, la acepta cuando está en juego la fidelidad a Dios que es en el fondo la fidelidad a su pueblo. Pero a Jesús lo matan en nombre de Dios, acusado de blasfemo, porque pone en peligro tanto el sistema religioso judío como el orden imperial.

Jesús no busca provocar su muerte, no es un suicida fanático. Al contrario, toma precauciones y, a veces, se escapa. En Jesús no hay en absoluto fanatismo necrófilo. Esta es una desviación religiosa relativamente frecuente, como lo vemos en nuestros días, y que se dio también en la Iglesia primitiva, en los "márti-

5. En el evangelio de Juan el conflicto de Jesús con los judíos es agudísimo. "Los judíos perseguían a Jesús porque hacía estas cosas en sábado" $(5,16)$; "trataban con mayor empeño en matarlo, porque no sólo quebrantaba el sábado, sino que llamaba a Dios su propio Padre, haciéndose a sí mismo igual a Dios" $(5,18)$. Más tarde, "Jesús andaba por Galilea y no podía andar por Judea, porque los judíos le buscaban para matarle" $(7,1)$. Y en el templo les pregunta: ¿por qué quieren matarme? $(7,19)$. La gente comentaba: “¿no es éste a quién querían matar?" $(7,25)$. Tras una discusión "quisieron detenerle, pero nadie le echó mano porque todavía no había llegado su hogar" $(7,30)$. Como hay mucha gente que cree en él, los fariseos "enviaron guardias para detenerle" $(7,32)$. Al final de otro discurso "tomaron piedras para tirárselas, pero Jesús se ocultó y salió del templo" $(8,59)$. En la fiesta de la dedicación, "los judíos trajeron piedras para apedrearle" $(10,31)$ y "querían prenderle, pero se les escapó de las manos" $(10,39)$. Cuando se dirige a Betania, enterado de la enfermedad de Lázaro, los discípulos le dicen: "Rabbí, con que hace poco los judíos querían apedrearte, ¿y vuelves allí?" $(11,8)$. Tras la resurrección de Lázaro, las autoridades judías deciden que Jesús es un peligro público, porque la gente se va tras él, lo que puede provocar una nefasta intervención de los romanos; y entonces, tiene lugar la requisitoria y la huida de Jesús de que se habla en el texto.

En el evangelio de Juan se refleja el conflicto de los cristianos con la sinagoga, que ha acabado expulsándolos de su seno. "Los judíos" es un concepto totalmente peyorativo en Juan, al revés de lo que aún se constata en el Apocalipsis $(2,9 ; 3,9)$. Pero la comunidad de Juan tampoco ha tenido éxito en su predicación a los paganos. Esta experiencia está detrás del "odio del mundo" contra los discípulos de Jesús. Esta comunidad tiene el peligro de encerrarse en sí misma y de convertirse en una secta. El amor al projimo, que llega hasta los enemigos (Mt 5, 44; 19, 9; Lc 6, 27; 25-27) es desplazado en el "mandamiento nuevo" joánico hacia los hermanos y los amigos. El peligro de una iglesia castigada y perseguida es convertirse en un ghetto cerrado. (Cfr. B. Kriegbaum, "La persecution dans I'Eglise primitive", Communio, marzoabril, 1987, pp. 24s). 
res voluntarios" que buscaban provocar su martirio como el camino más seguro para el cielo y para conseguir la máxima identificación con el Señor mo necrófilo acaba siempre generando violencia, porque cuando se está tan rápidamente dispuesto a morir por una causa con mucha más facilidad se suele estar dispuesto a matar por ella. Pero el perseguido en nombre de Jesús de Nazaret sabe una cosa decisiva: que él nunca podrá convertirse en perseguidor de nadie. Tendríamos que preguntarnos siempre cómo lue posible que una Iglesia perseguida y de mártires se convirtiera, tan pronto, en el curso de una sola generación, en perseguidora.

En Jesús no hay fanatismo necrófilo, pero sí hay fidelidad hasta la muerte, no simplemente a Dios, sino a la causa del Dios Padre, que se identifica con la vida de sus hijos y con la fraternidad.

La vida de los primeros seguidores de Jesús estuvo marcada por la persecución, que es un tema central en prácticamente todos los documentos del Nuevo Testamento. En un primer momento la hostilidad y la persecución procedían de su ambiente judío, tanto del círculo familiar como de la sinagoga. Hasta el año 63, con Nerón, la persecución fue la consecuencia de un conflicto intrajudío. En un segundo momento aparece la persecución de los cristianos por parte de la sociedad pagana, ante todo bajo la forma de hostilidad por parte de sus conciudadanos (calumnias, marginación, acusaciones...), pero también con intervenciones más o menos esporádicas de los tribunales y las autoridades.

En mi exposición voy a tratar, en primer lugar, de la persecución o conflicto en el mundo judío y, en segundo lugar, en el mundo pagano. Como he señalado, fundamentalmente fueron dificultades sucesivas, aunque en algunas comunidades -y lo reflejan algunos documentos del Nuevo Testamento- se encuentran ambas formas de conflicio.

Todos estos tipos de tribulaciones que conocieron los cristianos fueron antes experimentadas por Jesús: fue gravemente incomprendido en su familia e insultado con toda clase de reproches por las autoridades judfas, que lo persiguieron $y$, al final, lo condenaron por blasfemo: también fue condenado por la autoridad romana.

6. De los mártires voluntarios volveremos a hablar en el curso de este trabajo. Sobre ellos puede verse Martyrium Policarpi 4 (versión latina); Eusebio de Cesarea, HEY, 1. 6; Cipriano, Carta 81, 4. Tertuliano narra que en Asia muchos cristianos se autodenunciaban ante el gobernador Arrio Antonio. Este, exasperado, detuvo a algunos y despidió a los demás diciendo: "Desgraciados, si queréis mataros, ahí tenéis precipicios y cuerdas" (Ad Scopulam 5, I). 


\section{Persecución de los cristianos y conflicto intrajudío}

La primera forma de persecución que sufrieron los cristianos fue consecuencia de un conflicto entre grupos judíos rivales y tuvo, con toda probabilidad, un origen familiar?. Una serie de textos evangélicos que resultan duros y hasta escandalosos sólo se entienden cuando se leen a la luz del conflicto familiar que introducía el seguimiento de Jesús.

Hay que tener en cuenta la profunda unidad religiosa e ideológica de la familia patriarcal de ese tiempo. En el mundo greco-romano, incluido el judío, la religión tenía una base familiar (de culto y de transmisión de las creencias) y la familia constituía una unidad religiosa. Cuestionar la religión familiar era atentar contra sus vínculos más íntimos y contra el mismo orden social.

El comportamiento de Jesús, desinstalado, socialmente crítico y marginal, le creó conflictos muy graves con su propia familia (Mc 3, 20-21. 31-35) y, por eso, pudo anunciar las rupturas y dificultades familiares que iban a sufrir sus seguidores. Lo más probable es, desde un punto de vista histórico, que la ruptura con la familia no fuese una condición previa, sino una consecuencia del seguimiento de Jesús. Parece claro que Jesús puso la adhesión a su persona y la entrega a la causa del reino de Dios por encima de todos los vínculos sociales.

Encontramos ejemplos actuales que nos ilustran sobre lo que fue el conflicto y la persecución familiar en el cristianismo primitivo. Cuando un judío ortodoxo de nuestros días decide casarse con una persona no judía (y en el caso de los ultraortodoxos cuando desea casarse con quien no pertenece a la secta, aunque la persona sea judía) experimenta toda clase de presiones por parte de su familia para que no lo haga y si persiste en su idea es, con frecuencia, expulsado de su círculo familiar y hasta de su ambiente judío.

El seguimiento del Jesús terrestre y, con más razón, poco después, la fe en él como mesías crucificado-resucitado, provocó fuertes conflictos familiares. Con frecuencia, los mismos familiares denunciaban ante las autoridades judías a los seguidores de Jesús8.

7. W. H. C. Frend, op. cit, p. 176: "Parece que en las tres primeras décadas después de la crucifixión la persecución fue un conflicto fratricida entre grupos judíos rivales y este elemento mantuvo su fuerte presencia hasta el final del siglo Il. Las autoridades romanas sólo se sentían indirectamente amenazadas". En este apartado tengo que agradecer las numerosas sugerencias que me ha hecho oralmente mi amigo Santiago Guijarro, que está trabajando en una tesis sobre los textos de la familia en los evangelios, situándolos en su contexto histórico y cultural.

8. Es interesante observar que en el tiempo de que hablamos también la conversión al judaísmo implicaba, en la civilización greco-romana, la ruptura de las relaciones familiares pevias. Cfr. W. H. C. Frend, op. cit., p. 156. 
Estamos ahora en condiciones de entender algunos textos de los evangelios que en buena medida se remontan, en mi opinión, hasta el mnismo Jesús. Sin ánimo de ser exhauslivo ni de hacer un estudio completo, presento, primero, textos de la fuente $Q$ y, después, de la triple tradición.

\section{Lc 12, 51-53; Mt 10, 34-36 (Evangelio de Tomás 16)}

¿Piensan que he venido para dar paz a la tierra? No, se lo aseguro, sino división. Porque desde ahora habrá cinco en una casa y estarán divididos; tres contra dos y dos contra tres; estarán divididos el padre contra el hijo, y el hijo contra el padre; la madre contra la hija, y la hija contra la madre; la suegra conira la nuera, y la nuera contra la suegra.

Jesús afirma que su seguimiento provocará grandes conflictos en el seno de las familias. Este texto reúne todas las características para que pueda atribuirse al Jesús histórico: carácter implícito de la dignidad de Jesús, aire escandaloso y provocalivo de sus palabras. Es notable la referencia a la presencia suegranuera, que responde a la realidad familiar oriental, en la que el hijo lleva a su mujer a su casa paterna, donde queda bajo la autoridad inmediata de la suegra (el Evangelio de Tomás 16 elimina la relación suegra-nuera porque desconoce las características de la familia oriental).

Lc 14, 26 (Mt 10, 37; ET 55; cfr. Lc 9, 59-62; Mt 8, 21-22)

Si alguno viene a donde mi y no odia a su padre, a su madre, a su mujer, a sus hijos, a sus hermanos y hasta su propia vida, no puede ser discípulo mío.

Probablemente Jesús, aleccionado por su propia experiencia, alertó sobre las dificultades que sus seguidores iban a tener por parte de sus familiares. En todo caso, está claro que $\mathrm{Q}$ y después Mateo y Lucas utilizan estas palabras para fortalecer a los cristianos que sufrían estos conflictos. El mismo tema se encuentra en los dichos de la triple tradición.

\section{Mc 10, 28-30 (Mt 19, 27-29; Lc 18, 28-30)}

Yo les aseguro: nadie que haya dejado casa, hermanos, madre, padre, hijos o campos por $\mathrm{m}$ y el evangelio, quedará sin recibir el ciento por uno: ahora al presente, casas, hermanos, hermanas, madres, hijos y campos, con persecuciones; $y$ en el mundo futuro, vida eterna.

Se describe la casa que han tenido que abandonar los seguidores de Jesús: incluye el grupo de familiares, pero también los campos, la propiedad de la tierra, que era esencial a la familia e inseparable de ella. Esle abandono ha sido "por Jesús y el evangelio". La formulación de Mateo, "por mi nombre" $(19,29)$ 
expresa el término usado en las persecuciones contra la Iglesia primitiva.

La promesa a los seguidores de Jesús tiene dos pasos. En primer lugar se les promete que recuperarán centuplicado lo abandonado, ya ahora, en la comunidad cristiana. Esta comunidad, en efecto, es vista en otros lugares como una nueva familia $(3,3 \mathrm{l}-35)$, pero con una particularidad: esta nueva familia es una fraternidad radical donde no se reproducen las relaciones patriarcales (Mc 10, 30). Todo esto se recupera en la comunidad cristiana ciertamente, pero Marcos añade "con persecuciones". La vida cristiana se realiza bajo cl signo de la cruz. ¿De dónde proceden estas persecuciones?

Otros textos nos ayudarán a responder a esta pregunta, pero a la luz del texto que ahora consideramos parece que Marcos piensa en las persecuciones que proceden de la casa que se ha abandonado. En segundo lugar, a los seguidores de Jesús se les promete vida eterna9.

\section{Mc 13, 9-13 (Mt 10, 17-22; Lc 21, 12-17)}

Pero ustedes miren por ustedes mismos; les entregarán a los tribunales, serán azolados en las sinagogas y comparecerán ante gobernadores y reyes por mí, para que den testimonio ante ellos. $Y$ es preciso que antes sea proclamada la Buena Nueva a todas las naciones. Y cuando les lleven para entregarles, no se preocupen de qué van a hablar; sino hablen lo que se les comunique en aquel momento. Porque no serán ustedes los que hablarán, sino el Espíritu Santo. Y entregará a la muerte hermano a hermano y padre a hijo; se levantarán hijos contra padres y los matarán. Y ustedes serán odiados de todos por causa de mi nombre; pero el que persevere hasta el fin ése se salvará.

Este texto se encuentra en el discurso escatológico de Marcos y está mucho más reelaborado por la comunidad que los anteriomente presentados 10. Ante la pregunta que le dirigen los discípulos por los signos de la destrucción del templo y el fin del mundo $(13,4)$, Jesús responde con una doble advertencia (blepete en los versículos 5 y 9). La primera (vv. 5-8) hace referencia a los acontecimientos que precederán inmediatamente al fin del mundo. La segunda

9. El texto de Mateo, con el v. 28 que procede probablemente de $Q$ (Lc 22, 28-30), introduce una diferencia entre la suerte de Pedro y los discípulos históricos de Jesús, que en la resurrección se sentarán con el Hijo del Hombre en doce tronos para juzgar a las doce tribus de Israel, y la suerte de todos los demás discipulos de Jesús. Mateo también evita la distinción marcana "ahora al presente" y "en el mundo futuro", con lo que puede entenderse que la nueva familia, como la vida eterna, es cosa de la escatología.

10. R. Kühschelm, Jungerverfolgung und Geschick Jesu. Eine exegetischbibeltheologische Untersuchung des synoptischen Verfolgungsankïndigung Mc I3, 9-13 par. und Mt. 23, 29-36 par., Klosteneueburg, 1983. 


\section{LA PERSECUCION EN EL CRISTIANISMo PRIMITtVe}

adverlencia (vv. 9-13) hace referencia a las dificultades de la comunidad crrstiana en el próximo futuro. (En el lexto griego de los versículos 9 y 11 se repite cinco veces el pronombre "ustedes").

Estas dificultades son las persecuciones que van a sufrir. Se reitera que los fieles "serán entregados" (vv. 9.11.12), utilizando el verbo paradidomi, de carácter jurĺdico y con hondas evocaciones teológicas, porque es el usado para expresar la entrega de Jesús, tanto la del Padre a los hombres, como la de los hombres a la muerte.

Los cristianos serán entregados a los sunedria y serán azotados en las sinagogas (v. 9). Tendrán que comparecer ante gobernadores (hegemonôn) y reyes (Basileôn), lo que puede referirse a autoridades gentiles, pero no necesariamente, pues puede también designar a autoridades civiles judías, por ejemplo a los herodianos.

Pero el origen de la persecución está en sus propias familias judías; son sus propios familiares quienes denunciarán y entregarán a la muerte a los cristianos (v. 12), lo que hace, sin duda, a esta persecución especialmente dolorosa. Podemos imaginar una situación semejante a la de Zacarías 13, 3, en la que los padres rechazan y hasta matan al hijo que ha roto con las creencias religiosas tradicionales.

Como he señalado, este texto, absolutamente clave para nuestro tema, supone unas circunstancias posteriores a la vida de Jesús, y está también más reelaborado teológicamentell. Señalo las características más importantes de esta última naturaleza.

1. La persecución será "por Jesús" (v. 9), "por su nombre" (v. 13). No se los acusa de ningún delito o comportamiento delictivo, sino solamente de ser diferentes, de ser cristianos.

2. Contra lo que hubiese cabido pensar, la persecución contribuye a la misión. Ante los tribunales, gobernadores y reyes, compareciendo como acusados, los cristianos van a dar testimonio de Jesús (v. 9). Este testimonio ha sido visto, probablemente por el redactor, como formando parte del anuncio

11. Este dicho refleja temas velerotestamentarios (Is 19, 2; Miq 7, 2.6; Zac 13, 3). En lodos estos pasajes se habla de una situación extrema en la que los pilares de la sociedad se tambalean y se pervierten hasta los valores familiares. Esta radical convulsión, que se traduce incluso en el enfrentamiento encarnizado entre los miembros de la familia, es un signo de la desestabilización de este mundo y de la cercańa de la intervención de Dios. El tema de la ruptura familiar se desartollo en la apocalíptica judla hasta convertirse en un lugar común: Jub. 23, 16; 1 Hen. 100 , Is; 4 Q Test, 15-17; b San 97a; m Sotá 9, 15; Str. B. I 586-587; IV, 2, 981. Cfr. el trabajo de Santiago Guijarro citado en la nota. 
del evangelio a lodas las naciones (v. 10). De hecho, el ejemplo de los mártires convirtió a la le cristiana a muchos paganos e, incluso, a algunos de sus inismos perscguidores. El gran apóstol Pablo no ve la prisión que sulre en Efeso como un impedimento para su labor evangelizadora, sino al contrario. como un testimonio de su le y un estímulo que alienta a los hermanos: Filipenses I, 12-14. Y es que la persecución, como máxima identificación con Jesús, cs el lugar más iransparente para anunciar su mensaje.

3. Conlianza en medio de la persecución, evitando la preocupación obsesiva (me promerimmate) porque cl Espírilu Santo hablará en ustedes (v. 11).

4. Aparece otro tema que va a ser clave en la exhortación a los cristianos perseguidos. la perseverancia: "el que persevere (hupomeinas) hasta $\mathrm{cl}$ fin se salvará" (v. 13). Se utiliza el verbo perseverar-hupomeinô de la misma raíz que el substantivo hupomene, que va a aparecer conslantemente en la parenesis cristiana y que signilica "resistencia en medio de los sufrimientos".

No es posible cstudiar a tondo aquí las modificaciones que Mateo y Lucas introducen en este texio de Marcos 12. Lo más destacable es que Mateo (10, 17 22) silúa eslas palabras, a dilerencia de Marcos, en un contexto no escalológico, en un discurso a la comunidad cristiana, en el que se reitera el aviso de la persecución por parte de la familia y del ambiente judío (10, 17-20.21-22.3436). Se explica por la naturaleza fundamentalmente judeocristiana de la comunidad de Mateo. A la vez cste evangelista desarrolla en este capítulo tres tesis tcológicas relacionadas con la persecución, que o no se encuentran en Marcos o están sólo apenas insinuadas. Son las siguientes:

1. La persecución es una forma suprema de participar del deslino de Jesús: "No cstá el discípulo por encima de su maestro, ni el siervo por encima de su amo. Ya le basta al discípulo ser como su maestro, y al siervo como su amo. Si al ducño de la casa le han llamado Belzebú icuánto más a sus domésticos!" (Mt $10,24-25)$. Este es un tema absolutamente fundamental de la teología del martirio y de la persecución de la Iglesia primitiva.

2. La referencia a la escalología y al juicio final para fortalecer el testimonio cn medio de las persecuciones: "Por todo aquel que se declare por mí ante los hombres, yo también me declararé por él ante mi Padre que está en los cielos; pero a quien me niegue ante los hombres, le negaré yo también ante mi Padre que está en los cielos" (Mt 10, 32-33).

12. Lucas ofrece estas palabras de Jesús en el mismo contexto escatológico (21, 12-19) que Marcos y acentúa algún aspecto interesante: habla explicitamente de persecución y cárcel (v. 12); afirma con más claridad que la persecución y la cárcel serán ocasión para el testimonio misionero (v. 13); desarrolla la exhortación a la confianza (v. 14-15. 18a); usa ya el sustantivo hupomene (v. 19) tan importante en la exhortación cristiana primitiva. 
3. La exhortación a la conlïanza, a no tener miedo, incluso ante las amenazas contro la vida, son ampliamente desarrolladas con matcrial procedente de $Q$ (Mt 10, 26-31).

La persecución de los cristianos comienza, pues. históricamente como un conllicto intrajudío, que tienc su raíz en las casas y lamilias, pero que muy pronto pone en juego a las instituciones y autoridades del pueblo judío. Vamos a recordar los datos que encontramos en el Nuevo Testamento.

El primer mártir de la primitiva Iglesia es Esteban, uno de los líderes de la fracción cristiano-helenista. víctima del conflicto con los sectores judíos inás estrictos (Hch 6,8-15). Lucas asimila el martirio de Esteban a lá pasión de Cristo: lo acusan de lo mismo que a Jesús (Hch 6, 14; cfr. Mt 26, 59-61) y muere, como Jesús, perdonando a sus cnemigos (Hch 7,$60 ; c f r$. Lc 23, 24) y entregando al Padre su espíritu (Hch 7, 59; cfr. Lc 23, 46)।3. De esta lorma, Lucas presenta el martirio como la forma privilegiada de la imitatio Christi, lo que se va a convertir en un motivo martiriológico muy importante en la Iglesia primitiva. La persecución y el martirio de Esteban fue un puro conflicto judio hasta el punto de que parece que el prefecto romano Vitelo destituyó, el año 3637, al sumo sacerdote Caifás por este hecho, como Agripa II destituyó más tarde, en el año 62, al sumo sacerdote Anás por la muerte de Santiago, el hermano del Señorl4.

El primer martirizado de los doce fue Santiago, el Zebedeo, entre los años 41 al 44, por obra de Hcrodes Agripa, que buscaba con ello agradar a los judíos (Hch 12, I-3). Por esta misma razón, el rey apresó taınbién a Pedro, que fue milagrosamente liberado de la cárcel (Hch 12, 3-17). El conflicto intrajudío se agrava en Jerusalén y crece la desconfianza respecto a los seguidores de Jesús, a quienes se les cree vinculados con seclores judíos muy heterodoxos, porque en la diáspora admiten en sus comunidades a gentiles sin circuncidar. De hecho, a partir de este momento, Pedro tiene que irse de Jerusalén (Hch 12, 17) y la Iglesia de esta ciudad reafirma su fidelidad al judaísmo bajo la dirección de Santiago, el hermano del Señor.

La visión que nos presentan los Hechos de los Apóstoles de las persecuciones de la Iglesia primitiva está muy teologizada, pero en lo lundamental refleja la realidad histónica. Estas persecuciones proceden de las autoridades judias 150

13. En la tradición cristiana del siglo II, Esteban fue considerado el "mártir periecto". Cfr. W. H. C. Frend, op. cit. p. 63; Eusebio de Cesarea, H. E., Y, 2. 5; H. W. Surkau, Martyrien in jüdischer und frühchristlicher Zeit, p. II 7 ss.

14. M. Sordi, Los cristianos y el imperio romano, Madrid, 1988.

15. Es el caso de la persecución de los apóstoles en Jerusalén: Hch 4, 1-22; 5, 17-41; la de Esteban: 6, 8-15; 7, 54-60; la de los helcnilas: 8. 1-3; el rey Herodes, para agradar a los judfos, persigue a la iglesia, mata a Santiago y encarcela a Pedro: 12, 1-17. 
de las turbas judías que se amotinan contra los predicadores cristianos 16. Las autoridades imperiales no intervienen 17 y cuando son requeridas procuran, en lo posible, mantenerse al margen de lo que perciben como un conflicto intrajudio (Hch 18, 12-16); en Jerusalén los romanos salvan a Pablo de un posible linchamiento judío y se muestran respetuosos con el orden jurídico.

El caso de Pablo es bien notable, porque se encuentra alternativamente en los dos bandos de este conflicto intrajudío. Primero, como fariseo celoso, persigue a la Iglesia de Jerusalén, "entraba por las casas, se llevaba por la fuerza hombres y mujeres, y los metía en la cárcel" (Hch 8, 1-3); incluso, delegado del sumo sacerdote, va a Damasco para detener a los cristianos (Hch 9, 1-2). Una vez cristiano, Pablo es víctima de esa misma persecución que él había promovido, como nos narran los Hechos y testimonian las cartas del apóstol.

Hay que mencionar el martirio de Santiago 18 , el hermano del Señor, un judío fidelísimo y muy querido por el pueblo, que, sin embargo, fue asesinado a instancias del sumo sacerdote el año 61, aprovechando el vacío del poder romano ante el cambio de los procuradores. Es una fecha cercana ya al estallido de la revuelta judía del año 66. La efervescencia del nacionalismo judío era máxima, y con la eliminación de Santiago la autoridad sacerdotal buscaba probablemente congraciarse con los judíos, atacando a quien, pese a ser personalmente de un judaísmo intachable, representaba a una secta que mantenía relaciones, por diffciles que lueran, con unos judíos vistos como traidores a la identidad de su propio pueblo.

\section{La persecución por parte de los paganos}

La famosa persecución de Nerón del año 64 está rodeada de oscuridad, empezando por la dificultad para interpretar los textos que hablan de ella, pero lo que sí parece claro es que no se debió a un edicto emitido ex profeso contra los cristianos 19.

16. Es lo que les sucede a Pablo y Bernabe en Antioqula (13, 50-51) y en Iconio (14, 2.5-6.19). De esta experiencia saca Pablo una enseñanza importante: "es necesario que pasemos por muchas tribulaciones para entrar en el reino de Dios" (10, 22). Es el mismo tipo de persecución que conoce Pablo y Silas en Tesalónica (17, 5-8.13) y Pablo en Corintio (18, 12-17). Es también una turba judía la que se amotina en Jerusalén contra Pablo, queriendo darle muerte, de la que lo salvan los ramos que lo detienen y encarcelan $(21,11.27-28 ; 22,22-23.30 ; 23,12-15 ; 24,1-9)$. Un fenómeno distinto y único es la revuelta popular en Efeso contra Pablo, instigado por los orfebres de la ciudad, paganos, que defendian sus intereses económicos (19, 23-40).

17. Es una excepción el encarcelamicnto de Pablo y Silas en Filipo (Hch 16).

18. BJ II 15, 3; AJXX 9, 1; HE II 23, 4- I8.

19. Tácito, Anales, 15, 44, 2-5. Tácito alberga la sospecha de que la responsabilidad del 
Se ha solido considerar que con Domiciano (años $81-96$ ) volvió a arreciar la persecución, lo cual es hoy muy discutido por los historiadores, pero no hay duda de que este emperador tampoco dio una norma específica contra los cristianos.

Las grandes persecuciones, basadas en decretos emitidos contra los cristianos, empiezan más tarde, con el emperador Decio, a mediados del siglo IIl. Pero, ciertamente mucho antes, los cristianos experimentaron persecuciones bien reales en la sociedad pagana, bajo la forma de marginación social, difamaciones. denuncias ante los tribunales y condenas. En estas persecuciones se aunaron con frecuencia la oposición del ambiente pagano con la intervención de las autoridades.

Vamos a examinar dos documentos, la primera carta de Pedro y el Apocalipsis de Juan, en los que la persecución por parte de los paganos es central, pero que reaccionan de forma muy distinta ante ella. Ambos documentos pueden considerarse prácticamente contemporáncos, del último tercio del siglo I, y situados ambos en zonas cercanas de Asia Menor. Las formas tan distintas de reaccionar ante la persecución responden, en el fondo, a maneras distintas de entender la relación con el mundo. Pero en medio de este pluralismo, que es muy grande, encontramos también algunos contenidos teológicos compartidos.

\subsection{La persecución en la Primera Carta de Pedro}

En la primera carta de Pedro liene una singular importancia el tema de la persecución y de la relación de los cristianos con el mundo. Esta carta ha sido considerada "una encrucijada teológica" 20 , porque en ella resuenan muchos textos del Nuevo Testamento y se descubre un cierto eclecticismo teológico. Está escrita en nombre de Pedro, desde la Iglesia de Roma $(5,13)$, y está dirigida a una Iglesia de la misión paulina en Asia Menor. Es decir, reivindica la autoridad de la tradición petrina, pero tiene un parentesco innegable con la tradición teológica paulina (sobre todo con las cartas de la cautividad). Es probable que la primera carta de Pedro recoja un fondo teológico tradicional de origen litúrgico, que se refleja en otros documentos del Nuevo Testamento21.

incendio de Roma recae sobre el mismo Nerón, pero Plinio el Viejo se la alribuye explícitamente (Hist. Nat. 17, 1), e igualmente Suetonio (Nerón 38-39) y Dión Casio (Hist. 60, 46). Suetonio habla de pasada de la persecución de los cristianos en esta ocasión (Neron 16) y es en estas circunstancias probablementc donde hay que situar un importante texto de Clemente Romano (Ad Cor. V-VI).

20. A. Vanhoye. "I Pièrte au carrefour des théologies du Nouveau Testameni", en ACFEB, Esudes sur la Premiére Lettre de Pièrre, París, 1980, pp. 97-128.

21. Es lo que defiende M. E. Boismard, Pièrre (/ er. épitre), SDB., pp. 1447-1454. 
La primera carta de Pedro se dirige a unos cristianos que sufren persecución y pretende orientarlos con consejos prácticos y con reflexiones teológicas, y con la gran preocupación de reafinnar la identidad de la comunidad en medio de las dificultades. Ya al inicio se dice que los cristianos son "extranjeros en la dispersión" para dejar bien claro su siluación de marginación en medio de su sociedad22. Las comunidades son fundamentalmente de componente gentil $(4,3-4)$ y el problema les viene no de los judíos, sino del ambiente pagano y, quizá, de las autoridades imperiales.

\subsubsection{El origen de las persecuciones}

¿Dónde está el origen de las tribulaciones de estas comunidades cristianas? Se difunden en la sociedad graves calumnias sobre el comportamiento de los cristianos $(2,12 ; 3,16)$. También eran criticados porque rechazaban participar de las fiestas sagradas paganas, que iban acompañadas de excesos de diverso tipo (4, 3-4). Probablemente, esta actitud está en el origen de la "misantropía", del "odio del género humano" que reprocha Tácito a los cristianos23. Es posible que en 3, 15 haya una alusión a que los criśianos se veían obligados a comparecer ante los tribunales.

En cualquier caso, la hostilidad es más grave que la experimentada en tiempos de Pablo: no es ya sólo un contlicto entre judíos, y, además, se ha extendido por todas partes. "Los mismos padecimientos soportan sus hermanos dispersos por el mundo entero" $(5,9)$; "no se soprendan como de un suceso extraordinario del incendio que se ha producido entre ustedes" $(4,12)$. Es particularmente interesante esta invitación a no sorprenderse, a considerar como algo normal en la vida cristiana el conflicio con el mundo.

Un último texio: "Sean sobrios y velen. Su adversario, el Diablo, ronda como león rugiente, buscando a quién devorar. Resístanle firmes en la fe" $(5,8$ 9). La imagen del león es alusión al Salmo 22, 14, donde se usa para expresar las amenazas que rodean al justo, pero cabe preguntarse si no estará también aludiendo al martirio ante las fieras, que para estos momentos ya han sufrido algunos cristianos 24 .

22. Se ha solido interpretar "parepidemois diasporas" como referencia a la patria celeste, lo que hace que los cristianos se sientan extranjeros en toda tierra. Elliot defiende, por el contrario, que alude a la situación sociológica de marginación en que se encontraban los destinatarios de la carta en su sociedad: A Home for the Homeless. A sociological Exegesis of I Peter, its Situation and Strategy, Philadelphia, 1981.

23. Annales XV, 44. La acusación de "misantropia" ya se dirigla contra los judíos. EI monoteísmo exclusivista de los judios y de los cristianos los separaba de las manifestaciones sociales marcadas por el paganismo.

24. Cfr. C. Lepelly, "Le contexte historique de la premiere lettre de Pierre", en ACFEB,Erudes sur la premiere leltre de Pierre, París, 1980, p. 64. 


\subsubsection{Preocupación apologética de la primera carta de Pedro}

Ante esta siluación la carta hace una exhortación constante: con su buen comportamiento demuestren la lalsedad de las calumnias que les dirijan.

Tengan en medio de los gentiles una conducta ejemplar a fin de que, en medio de los que les calumnian como malhechores, a la visla de sus buenas obras den gloria a Dios en el Jía de su visita... Pues ésla es la voluntad de Dios: que obrando el bien cierren la boca a los ignorantes insensatos (2, 12.15).

Y ¿quién les hará mal si se ałanan por el bien?... Mantengan una buena conciencia, para que aquello mismo que les echen en cara, sirva de confusión a quienes critiquen su buena conducta en Cristo. Pues inás vale padecer por obrar el bien, si esa es la voluntad de Dios, que por obrar el mal (3. 13.16-17).

Dichosos ustedes si son injuriados por el nombre de Cristo, pues el Espíritu de gloria, que es el Espíritu de Dios, reposa sobre ustedes. Que ninguno de ustedes tenga que sufrir ni por criminal ni por ladrón ni por malhechor ni por entrometido; pero si es por cristiano, que no se avergüence, que glorifique a Dios por llevar este nombre $(4,16-17)$.

Este afrontar la persecución explica uno de los temas más importantes y, con frecuencia, malinterpretados de la primera carta de Pedro: su exhortación a los cristianos para que se sometan al orden establecido ("por amor del Señor estén sometidos a toda institución humana", 2, 13). Y esto tiene dos vertientes, con las que se pretende abarcar los aspectos vitales de aquella sociedad. En primer lugar, pide a los cristianos que se sometan a las autoridades políticas, al emperador y a los gobernadores, que son delegados suyos $(2,14)$. En segundo lugar, pide respeto al orden doméstico, que era la base de aquella sociedad: los siervos deben someterse a sus amos y las mujeres a sus maridos. Es decir, se inculca el respeto al orden patriarcal $(2,18-3,7)$.

Es importante captar lo que está en juego en estas exhortaciones. Lo que se pretende es acabar con las acusaciones que se dirigían contra los cristianos de perturbar el orden social, de no aceptar las leyes del imperio y de romper las unidades domésticas, todo lo cual estaba en el origen de la animadversión popular y de las persecuciones consiguientes.

El orden imperial y el doméstico formaban una unidad en aquella sociedad y el autor de la carta los presenta como tal2s. Por eso, el código doméstico está

25. La casa era la estructura base de todo el edificio social y el sistema político estaba constituido por la suma de muchas casas, y su orden debía rellejar, a una nivel más amplio, el orden de una buena casa patriarcal. Cfr. R. Aguirre, Del Movimiento de Jesús a la Iglesia Cristiana, Bilbao, 1987, especialmente páginas 65-92. 
enmarcado por dos exhortaciones que se refieren a las autoridades políticas. A] comienzo dice: "sean sumisos, a causa del Señor, a toda institución humana: sea el rey, como soberano, sea a los gobernantes, como enviados por él para castigo de los que obran el mal y alabanza de los que obran el bien" (2, 13-14). Y cuando termina de señalar los deberes domésticos, afirma: "estén siempre dispuestos a dar respuesta a todo el que les pida razón de su esperanza" $(3,15)$.

La primera carta de Pedro liene con las autoridades imperiales y con la sociedad pagana una actitud posibilista. Pretende echar puentes, evitar la persecución en lo posible, hacer comprensible el comportamiento de los cristianos. Es una actitud que guarda semejanza con la de Pablo en Romanos 13, pero que es muy diferente a la del libro del Apocalipsis.

La postura de la primera carta de Pedro tiene un notable parecido con la que van a mantener los grandes obispos en tiempo de las persecuciones posteriores. Por una parte, son conscientes de que la persecución puede hacer flaquear la fidelidad de muchos cristianos (el problema de los lapsi) e, incluso, puede poner en peligro la supervivencia misma de la comunidad, lo cual lleva a intentar, en lo posible, quitar razones a los perseguidores y, sobre todo, a moderar el celo imprudente de "los mártires voluntarios", aquellos cristianos un tanto fanáticos que intentaban provocar el martirio. Pero, por otra parte, y como no podía ser menos, la primera carta de Pedro tiene muy claros los límites de todo poder humano y de que "hay que obedecer a Dios antes que a los hombres" (Hch 5 , 29), y liama a la perseverancia en la persecución y hace una de las más hondas teologías de la persecución de todo el Nuevo Testamento.

\subsubsection{Circunstancias históricas de la persecución}

Pero antes de entrar en estas reflexiones también debemos abordar un problema histórico de gran importancia.

Los cristianos son perseguidos por las difamaciones que corren sobre su comportamiento. Ya hemos visto que la carla insiste en la necesidad de que la conducta ejemplar de los cristianos debe intentar convencer a sus enemigos. El esfuerzo de la carta por dialogar constantemente con su sociedad es muy grande, como corresponde a quien desea defender a una comunidad de gente humilde e, incluso, posibilitar un proyecto misionero. El tono de la carta es de un cierto optimismo sobre el impacto del comportamiento de los cristianos (cfr. 3, 13). Pero es realista, y añade "y si con todo padecieran por la justicia, bienaventurados ustedes" $(3,14)$.

Pero la carta cuenta también con la posibilidad de que los cristianos sean perseguidos, no ya por su conducta, calumniosamente deformada, sino por el 


\section{LA PERSECUCION EN EL CRISTIANISMO PRUMITIVO}

mero hecho de ser cristianos. (4, 14 en onomati Christou; 4, 16 hos christianos) 26 .

Dichosos ustedes si son injuriados por el nombre de Cristo, pues el Espíritu de gloria, que es el Espíritu de Dios, reposa sobre ustedes. Que ninguno de usledes tenga que sufrir ni por criminal ni por ladrón ni por malhechor ni por entrometido; pero si es por cristiano, que no se avergüence, que glorifique a Dios por llevar este nombre $(4,14-16)$.

Se ha discutido mucho si los cristianos fueron perseguidos por los flagitia (comporamientos aborrecibles) o por el nomen (por el hecho de ser cristianos). No sería procedente argumentar con los edictos de las grandes persecuciones, que son de un tiempo posterior. Lo que parece claro es que en Asia Menor, a finales del siglo I, ambas razones están en el origen de las graves dificultades que los cristianos tienen con su ambiente pagano y con las autoridades. La opinión pública los hacía reos de comportamientos aborrecibles y también su mera identificación como cristianos podía provocar su persecución por parte de las autoridades.

Aquí es obligado mencionar el conocido intercambio epistolar entre Plinio el joven, gobernador de Bitinia, y el emperador Trajano. Plinio había sido nombrado con el encargo tajante de velar por el orden público, fuertemente cuestionado en las regiones de Asia Menor por facciones y grupos rivales.

La autoridad imperial veía con especial desconfianza a los hefarai o collegia, asociaciones voluntarias de diversa naturaleza, porque se los consideraba fuente de rivalidades y connictos. Plinio recibió la orden de suprimir el derecho de asociación, es decir, los hetarai27. Esta medida se aplicó tan rigurosamente que Trajano llegó a prohibir la creación de un cuerpo de bomberos en Nicomedia, iniciativa a la que Plinio era favorable28.

Este transfondo nos permite situar mejor el problema especifico planteado por los cristianos. En el año 112, Plinio escribe al emperador para preguntarle por la actitud que debe adoptar con los cristianos conducidos a su tribunal29. Sus dudas son tres. La primera era si debía tomar en consideración la edad del acusado. Esta era una cuestión que se dejaba al arbitrio del gobernador y, quizá

26. Cfr. G. Betori, Perseguitati a causa del nome, Roma, $198 \mathrm{I}$.

27. Lepelley, op. cit., p. 56; W. H.C. Frend, op. cit., pp. 166 ss.

28. Lepelley, op. cir., p. 56.

29. Plinio, Carta X, 96-97. Una edición muy cómoda de los textos en R. Penna, Ambiente hisıórico-cultural de los orígenes del cristianismo, Bilbao, 1994. pp. 324 327. Los estudios son numerosísimos. Me parecen de especial utilidad los de C. Lepelley en el artículo cilado y el de G. E. M. de Ste. Croix, "Las persecuciones", en A. Toynbee (ed). El crisol del cristianismo. Historia de las civilizaciones 4,

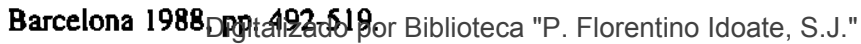

Universidad Centroamericana José Simeón Cañas 
por eso, Trajano no responde. La segunda duda era si podía perdonar a aquellos que, arrepentidos, apostataran de su fe. Y la tercera era si debía castigarse "sólo por el nombre" (simplemente por profesar el cristianismo), aunque no se alegaran flagitia, o bien por los flagitia relacionados con los cristianos.

En realidad, el problema grave era sólo uno. Era claro que quienes negaban haber sido cristianos debían ser liberados y que quienes confesaban ser cristianos debían ser condenados. ¿Pero sólo por el mero hecho de ser cristianos ("por el nombre") o por los flagitia que esta confesión implicaba? Y quienes apostataban del nombre, ¿debían ser liberados o, por el contrario, debían ser castigados por los flagitia cometidos?

La respuesta de Trajano es concisa y resolutiva. Primero, se prohíbe buscar expresamente a los cristianos. Segundo, las actuaciones deben iniciarse cuando hay una acusación formal para evitar acusaciones malintencionadas, de modo que se castigue a quien se pruebe que ha calumniado. Por último, Trajano ordena que "quienquiera que niegue ser cristiano y lo demuestre invocando a nuestros dioses sea perdonado en razón de su arrepentimiento, por muy dudosa que haya sido su conducta pasada". Es decir, la persecución debe ser sólo por el nombre y no hay que tener en cuenta las acusaciones de flagitia 30 . He aquí el texto:

Caro Segundo, has seguido acendrado proceder en el examen de las causas de quienes fueron denunciados como cristianos. No se puede instituir una regla general, es cierto, que tenga, por así decir, valor de norma fija. No deben ser perseguidos de oficio. Si han sido denunciados y han confesado, han de ser condenados, pero del siguiente modo: quien niegue ser cristiano y haya dado prueba manifiesta de ello, a saber, sacrificando a nuestros dioses, aun cuando sea sospechoso respecto al pasado, ha de perdonársele por su arrepentimiento. En cuanto a las denuncias anónimas, no han de tener valor en ninguna acusación, pues constituyen un ejemplo detestable y no son dignas de nuestro tiempo $(\mathrm{X}, 97)$.

Esta respuesta de Trajano estableció la jurisprudencia que sirvió de referencia para las persecuciones hasta el siglo III. La primera carta de Pedro presupone una situación anterior, en la que los cristianos podían ser perseguidos no sólo por el hecho de serlo sino también por crímenes imaginarios. Esta carta debe situarse a fines del siglo I, antes del rescripto de Trajano.

30. G. E. M. de Ste. Croix, op. cit., 500. Hay varios textos cristianos en que se ve que la persecución es "por el nombre", por el hecho de ser cristianos, lo que lleva a los autores a defenderse pidiendo que se examine su conducta: Justino, I Apología, 4, 1-

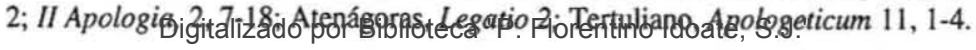

Universidad Centroamericana José Simeón Cañas 


\subsubsection{Teología de la persecución y del martirio}

Pero en la primera carla de Pedro además de estos consejos práclicos de molivación apologética, que buscan una adecuada inserción de las comunidades cn el mundo, encontramos una prolunda teología de la persecución, que utiliza y desarrolla la tradición evangélica. Voy a exponer brevemente sus puntos principales.

1. El cristiano no debe extrañarse de la persecución. "Queridos, no se extrañen del incendio surgido entre ustedes para su prueba, como si les sucediera una cosa cxtraña" $(4,12)$. Esta observación es tanto más notable por encontrarse en un escrito con una preocupación muy grande para que los cristianos eviten las causas de la persecución. Pero lambién sabe que la fe cristiana introduce un germen crítico respecto al mundo, que conlleva siempre la probabilidad del conllicto y del enlirentamiento. La primera carta de Pedro no propugna ciertamente la actitud de una secta que se repliega y se cierra en sí misma, porque quiere abrirse a su sociedad y acreditarse ante ella; pero tampoco es una Iglesia que lleva su esfucrzo de acomodamiento hasta el punto de diluir la novedad incómoda de la fe.

El cristiano tiene que encarnarse en el mundo para que su fe sea relevante en medio de las circunstancias históricas cambiantes y de las diversas culturas; pero la encarnación no debe equivaler a la mundanización que diluye la novedad de su fe y olvida la tensión con su sociedad. La reivindicación del conflicto no dehe servir para justificar desajustes personales de carácter psicológico ni para legitimar el encastillamiento sectario ni para encubrir la incapacidad para dialogar con el mundo aprendiendo de él y descubriendo los signos del Espíritu que en él se encuentran. Pero también hay que decir que una actitud coherente cristiana siempre mantendrá una cierta capacidad crítica con su entomo social y no deberá extrañarse de tener que asumir el conflicto.

2. La alegría en medio de la persecución. La alegría es una característica fundamental de la vida cristiana. Creer en el Dios de Jesús es algo bueno, un tesoro cuyo descubrimiento cambia la existencia. El creyente experimenta como algo bueno y humanizante encontrarse con Dios. La experiencia pascual es siempre una experiencia de paz y alegría.

En medio de las maledicencias, del ostracismo social, de los conflictos y de la persecución abierta, el cristiano siente esa alegría que procede de Dios y que nadie puede arrebatarle de su corazón (Jn 16, 20-22).

No es retórica ni frases hechas pero vacías, sino que son realidades confirmadas por la vida. Podríamos aludir a los actas de los mártires. Yo puedo testificar de la alegría y la afirmación gozosa de la vida que se encuentra en tantas comunidades cristianas de gente muy sencilla, la mayoría, por ejemplo en Centroamérica, en las que la supervivencia física es un riesgo cada día, cuando 
no es que se ven bajo el peligro de la opresión y de la violencia.

En la medida en que participan (koinoneite) en los padecimientos de Cristo alégrense (chairete) para que también en la revelación de su gloria se alegren alborozados (charete agalliomenoi) $(4,12)$.

Dichosos (makarioi) si son injuriados por el nombre de Cristo, pues el Espíritu de gloria, que es el Espíritu de Dios, reposa sobre ustedes $(4,14)^{31}$.

Nos enconiramos con un comentario a la bienaventuranza de la persecución de los evangelios.32:

Bienaventurados los perseguidos por causa de la justicia, porque de ellos es el reino de los cielos (Mt 5, 10).

Bienaventurados serán cuando los injurien, los persigan y digan con mentira toda clase de mal contra ustedes por mi causa. Alégrense y regocíjense (chairete kai), porque su recompensa será grande en el cielo (Mateo 5, 11 12).

En la primera carta de Pedro resuena la tradición evangélica cuando llama bienaventurados tanto a los fieles que sufren por los flagitia (delitos abominables de que eran acusados) como a los que sufren por el nombre (por el mero hecho de ser cristianos). En 3, 14 es indudable la alusión a Mateo 5, 10: "aunque sufrieran a causa de la justicia, dichosos ustedes". Como ya hemos visto, en 4,12 se alude a Mt $5,11$.

La carta habla de la alegría ya ahora, en medio de los padecimientos, porque ahí se da la máxima identificación con Cristo, porque ahí cuentan con la presencia del Espíritu de Dios de una forma singular, y porque exultarán de gozo cuando se revele plenamente su gloria. Se trata de alegrarse no sólo "siendo", sino "por ser perseguidos. Es una alegría paradójica que no viene después de la cruz, sino en la cruz misma33.

31. Es interesante notar los contactos entre 1 Ped 4, 12, "no se extrañen del fuego que ha prendido en medio de ustedes para probarlos (peirasmon humin) como si algo extraño les sucediera (humin sumbainontos)" y Hech 20, 19, que también habla de la persecución, "con las pruebas que me sucederian (peirasmôn tôn sumbantôn moi) por las asechanzas de los judlos".

32. La comparación detallada entre las bienaventuranzas de Mt-Le y la 1 Pedro en J. Cervantes, La pasión de Jesucristo en la Primera Carta de Pedro, Estella, 1991, p. 306ss. Cfr. W. Nauck, Freude im Leiden: Zum Problem einer urchristlichen Verfolgungstradition, ZNTW XLVI (1955) pp. 68-80.

33. J. Cervantes, op. cir., p. 307. La expresión charete agalliomenoi de IPd 4, 13 para expresar la alegría escatológica fulura es empleada con el mismo sentido en Apoc 19. 7. Mi 5, 12 la refiere al gozo que el perseguido debe sentir ya en el presente, pero en vistes de la futura recompensa. 
Es la experiencia de los apóstoles, que tras haber sido encarcelados y azotados, "marcharon de la presencia del Sanedrín contentos por haber sido considerados dignos de sufrir ultrajes por el Nombre" (Hch 5, 4I).

Ya al inicio ( 1 Ped 1,6 ) se afirma la situación paradójica en que viven los cristianos reengendrados a una vida nueva y llamados a una gran esperanza y, por tanto, "llenos de gozo, aunque ahora tengan que entristecerse un poco, en las diversas pruebas". La carla de Santiago, con expresiones parecidas, formula más radicalmente el gozo en medio de la persecución: "lengan, hermanos míos, por sumo gozo verse rodeados de diversas pruebas" (Sant 1, 2).

Pero es Pablo quien con más fuerza ha descrito la situación paradójica de dificultad, fatigas y persecución, y, a la vez, gozo, paz y alegría: "como entristecidos, pero siempre alegres; como pobres, pero enriqueciendo a muchos; como quienes nada tenemos, aunque poseemos todo" (2Cor 6,10$)$.

3. La persecución como participación en los sufrimientos de Cristo. En la primera carta de Pedro hay una teología cristológica de la persecución de los cristianos. En la persecución, el cristiano sigue el ejemplo de Cristo; más aún, ahí se da la máxima identificación con él. Es el punto más importante, ya mencionado, que conviene desarrollar.

Es muy posible que la primera carta de Pedro recoja elementos de la catequesis tradicional, pero probablemente nos encontramos con la teología más profunda y más específicamente cristiana de la persecución en el Nuevo Testamento. Es una reflexión que nace desde las experiencias de comunidades marginadas y perseguidas, que tienen su punto de referencia en la vida de Jesús y que releen a su luz el Antiguo Testamento, concretamente los cánticos del Siervo de Yahvé de Isaías.

Después de la mención de la persecución viene inmediatamente la referencia al ejemplo de Cristo:

Si obrando el bien soportan el sufrimiento, esto es cosa bella ante Dios. Pues para esto han sido llamados, ya que también Cristo sufrió por ustedes, dejándoles ejemplo para que sigan sus huellas (2, 20-21).

A continuación explicita este ejemplo de Cristo con un himno (2, 21-25), que relee Isaías 53, 4-9.12 y lo aplica a la vida de Jesús.

En 3, 17-18 vuelve a contemplar la posibilidad de padecer haciendo el bien (siempre la preocupación apologética por evitar los flagifia), y lo vuelve a poner inmediatamente en relación con Cristo que "también sufrió34 una vez por los pecados, el justo por los injustos para llevarnos a Dios".

34. Algunos manuscritos en vez de sufrió leen murió. Mi preferencia se debe a que sufrió es la lectura que encaja mejor con el contexto y teológicamente es más extraña. 
La relación del perseguido con Cristo alcanza su formulación más profunda en un texto ya cilado: "alégrense en la medida en que participen de los padecimientos de Cristo" (4. 13). El cristiano perseguido, marginado, calumniado, no sólo sigue los pasos de Cristo —omo decía 2, 21—, sino que participa de sus mismos padecimientos. La primera carta de Pedro formula teológicamente lo que los Hechos de los Apóstoles querían decir con su forma de presentar la muerte de Esteban: en el martirio se da la más perfecta identificación con Cristo. Esta teología nace de la contemplación de la vida de Jesús, es específicamente cristiana y se distancia notablemente de la teología del martirio propia del judaísmo.35.

\subsection{La persecución en el Apocalipsis}

Este libro reacciona de una forma muy diferente a la de la primera carta de Pedro ante unas persecuciones muy similares. Se trata de una obra compleja, llena de imágenes y de símbolos procedentes del Antiguo Testamento (sobre todo del Exodo, Ezequiel y Daniel) y del mundo pagano, de difícil interpretación.

\subsubsection{La persecución del imperio pagano}

¿De dónde viene la tribulación y la persecución bajo cuyo peso vive continuamente la comunidad? El Apocalipsis conoce la hostilidad y la persecución de parte de los judíos, de "los que se llaman judíos sin serlo y son en realidad una sinagoga de Satanás" $(2,9 ; 3,19)$. Pero lundamentalmente la persecución procede del imperio romano. Es el sentido de la conocida imagen de la Bestia que surge del mar (capílulo 13), que alude claramente a las bestias de Daniel 7, que también surgen del mar y que representan a los reinos opresores de Israel, contrapuestos a una nueva figura, que no viene del mar sino que viene con las nubes del cielo, y que no es una bestia, sino una figura humana, un hijo del hombre. A esta Bestia del Apocalipsis, el Dragón le confiere "su poder y su trono y gran poderío" $(13,2)$. Detrás está la idea de que Satanás es el señor de este mundo y confiere el poder a quien quiere (Jn 12,31; Lc 4,6). Esta Bestia poderosa, el poder imperial divinizado, exige adoración, profiere blasfemias y lleva tras de sí al mundo entero: "La tierra entera siguió maravillada a la Bestia" $(13,3 ; c f r .13,8)$.

35. La vinculación entre la gloria destinada a los cristianos y los padecimientos de Cristo aparece ya en el inicio de la carta (1, 10-12). Los profetas del Antiguo Testamento vislumbraron la plenitud de gracia del tiempo mesiánico. que conocen los cristianos, y vislumbraron también los padecimientos de Cristo (el autor piensa, con toda probabilidad, en los cánticos del Siervo del Señor, que después él va a aplicar a Cristo). 


\section{LA PERSECUCION EN EL CRISTIANISMO PRIMTtTa}

La Bestia del poder político cuenta con instancias ideotógıcas que Ja legitiman y convencen al pueblo para que acepte sus pretensiones totalitarıas: "VI otra Bestia que salía de la tierra... y hablaba como un dragón... y extravió a los moradores de la tierra" $(13,11.14)$. Llega un momento en el que quien no acepta la marca de la Bestia "no puede ni comprar ni vender" (13, 16-17). Quien se resiste a adorar a la Bestia, quien no se doblega a su dominio y no acepta su visión del mundo, queda excluido y marginado de la vida social y ve peligrar su misma existencia.

\subsubsection{Resistencia y perspectiva escatológica}

El mensaje del Apocalipsis es tajante: "Sal de Babilonia pueblo mío" $(18,4)$. Hay que resistir a la Bestia y no cabe ningún tipo de compromiso con ella. No hay esfuerzos apologéticos ante el perseguidor como en la primera carla de Pedro. Todas las energías se concentran en la resistencia. La máxima virtud cristiana es la resistencia perseverante en el sufrimiento (hupononê): "se requiere la resistencia perseverante, la fe de los santos" $(13,10)$, "la resistencia perseverante y la fe de Jesús" $(19,12)$ para no ceder a la Bestia. El gran elogio a la Iglesia de Filadellia es que "guardaste mi palabra de resistencia (eteresas ton logon tes hupomonês mou)" $(3,10)$.

El Apocalipsis consuela a estas comunidades marginadas, que sufren con la visión del triunfo que espera a los mártires, a quienes no se fueron tras la Bestia, a quienes no fornicaron, es decir, a quienes no cedieron ante el culto idolátrico. La ingente multitud de los salvados "son los que vienen de la gran tribulación y lavaron sus túnicas y las blanquearon en la sangre del Cordero" $(7,14 ; 6,9 ; 12$, $11.17 ; 14,4-5 ; 17,6 ; 18,24 ; 20,4)$.

En el Apocalipsis, la comunidad cristiana aparece en una situación crítica, en la que no caben situaciones de compromiso y en la que el martirio es una posibilidad muy real. Resulta una visión de la historia dilemática y hasta dualista. Roma es demonizada, en una visión muy diferente a la que encontramos en Pablo y en la primera carta de Pedro, y el mártir es el seguidor por antonomasia del Cordero degollado, el prototipo de todos los mártires (1, 5; Policarpo, VIII, 2).

El Apocalipsis presenta dos imágenes de enorme impacto visual y emocional, que señalo brevemente. En los capítulos 4 y 5 se describe a Dios sentado en su trono con toda la imaginería de un soberano en su estancia real. El Señor del mundo no es el emperador romano, sino Dios.

La cuestión central de estos capítulos, como de todo el libro, es: ¿quién es el auténtico Señor de este mundo?.... Entronizado con el poder y la majestad divina, el Cristo vencedor ejerce, con Dios, el verdadero señorío sobre el mundo. En el lenguaje del simbolo y del mito, los capítulos 4 y 5 desarrollan 
la alimmación final de 3, 21 ... Juan describe el cielo no como un templo, sino como la sala del trono de un soberano real o romano. Como el emperador romano era pintado rodeado de amigos y consejeros cuando dispensa justicia, así es visto Dios en su papel de juez ${ }^{36}$.

También se establece una contraposición entre dos ciudades, descritas con rasgos de liguras lemeninas: por una parte, la gran ramera ${ }^{37}$, sentada sobre las grandes aguas (capítulo 17), la Bestia que surge del mar (capítulo 13), la gran Babilonia (todas son imágenes de Roma), la madre de las rameras y de las abominaciones de la tierra $(17,5)$. Roma es vista como intoxicada con la sangre no sólo de los santos, sino también de todos los degollados sobre la tierra (18, 24). Por otra parte, la ciudad santa, la nueva Jerusalén que desciende del cielo del lado de Dios, ataviada como una esposa que se engalana para su esposo (capílulo 21). Hay que salir de Babilonia $(18,4)$, no hay que prostituirse con la ramera, no hay que dejarse fascinar por la Bestia para poder participar de la otra ciudad, la definitiva, la Jerusalén que desciende de Dios "ataviada como una esposa para su esposo" $(21,2)$. El centro de la nueva ciudad de Dios es el trono de Dios, que se contrapone al trono símbolo del poder y de la soberanía imperial. No sólo la comunidad cristiana, sino todas las naciones serán el pueblo de Dios $(21,3 ; 15,3)$. EI establecimiento del reino de Dios y de Cristo en la tierra trae la salvación total no sólo para los cristianos, sino para todos los martirizados y oprimidos por el presente poder político $(18,24)$.

Así como la ciudad Babilonia-Roma representaba al imperio romano reuniendo el poder político y la riqueza comercial de las naciones y de sus jefes, así lambién la nueva Jerusalén contendrá el poder y el esplendor de las naciones. Pero mientras Babilonia-Roma malutilizó su poder y su riqueza para comomper y destruir la tierra, la visión escatológica del imperio universal de Dios promete nueva vida, salud y fraternidad. El trono —el símbolo del poder de Dios del que procede todo juicio- se convierte ahora en la fuente de vida eterna y de felicidad $(22,1-3)^{38}$.

36. E. Schüssler Fiorenza. Revelation. Vision of a jus! world, Minneapolis, 1991, pp. 58 s.

37. La figura de la proslituta simboliza frecuentemente en el Antiguo Testamento un pueblo o una ciudad id6latra; cfr. Is 1, 21; 23, 16-18; Ez 16, 15-63; Os 2; 5, 3; Nah 3. 4. Aquí se trata verosímilmente de la Roma imperial, lugar alto del paganismo idólatra y de la potencia perseguidora ( $v$. 6). Así se explica que sea descrita al borde de las aguas ( $v .1$ ) y sentada sobre una bestia de siete cabezas, que según el v. 9 significa las siete colinas de Roma. Cfr. nota de la TOB a Apoc 17, 1.

38. E. Schussler Fiorenza, op. cir., p. 113. 


\subsubsection{La paradoja de la existencia cristiana}

La situación de crisis que viven las comunidades resulta profundamente paradójica. Si Jesucristo ha vencido a la muerte ¿cómo es posible que los cristianos ahora sean perseguidos hasta perder la vida? Si Dios es el Señor del universo, ¿por qué el emperador romano es quien domina despóticamente en estos días? Juan, el profeta que transmite la visión consoladora que Dios le ha concedido, comparte esta situación paradójica $\psi$ se confiesa "partícipe con ustedes en la tribulación (zlipsei), en el reino (basileia) y en la resistencia perseverante (hupomone) en Jesús" $(1,9)$. Los tres rasgos van precedidos de un artículo único, porque son inseparables y forman una sola experiencia: en primer lugar, participación en la tribulación, la marginación, la persecución y el martirio; en tercer lugar, participación en la resistencia y perseverancia; pero en el segundo lugar, en medio de todo eso y al mismo tiempo, paradójicamente la participación en el poder de Jesús, una realidad desconcertante para el mundo, León de Judá y Cordero degollado $(5,5-6)$, que, sin embargo, está en pic para siempre, que ha muerto pero que vive por los siglos $(1,18)$.

Las visiones del Apocalipsis no pretenden nunca especular sobre el futuro ni sobre el curso de la historia, sino fortalecer la esperanza y la resistencia de los creyentes en Jesús ${ }^{39}$. EI libro está transido de la alegrfa y de los cantos de vicloria que entonarán al fínal los mártires que no claudicaron ante la Bestia y permanecieron fieles a Dios y al Cordero (15, 2-3; 19, 1-10). Cuando Babilonia es aniquilada se oyen los lamentos de quienes gozaban con su poder y se beneficiaban de sus riquezas y de sus redes comerciales (capítulo 18), pero a continuación se escuchan los cantos de alabanza y los aleluyas de la muchedumbre numerosa de los salvados (19, I-2. 3. 6b. 9). Se trata de la alegría escatológica, la que espera a los fieles en el futuro y que ya en el presente debe fortalecer su resistencia y esperanza. Pero es muy diferente a la alegría que experimenta ya en el presente quien sufre por Cristo, tal como la presentna las bienaventuranzas y la primera Carta de Pedro.

\subsubsection{Circunstancias históricas y función social del Apocalipsis}

¿Qué podemos decir de la situación hislórica, real, de las comunidades a las que se dirige el libro del Apocalipsis?40. Hoy tiene muy pocos seguidores la

39. E. Schüssler Fiorenza, op. cit., p. 36.64.117. Ph. Esler, "Political Opression", en Jewish Apocalyptic Literature: A Social-cientific Approach, Lissening. Journal of Religion and Culture 28 (1993) pp. 181-199 indica que la función social de esta literatura es fortalecer la identidad del grupo.

40. Discusión sobre la Techa del Apocalipsis en J. Collins, Dating the Apocalyse of John, BR 26 (1981) pp. 33-45. La opinión tradicional lo asignaba al tiempo de Domiciano: Irineo, Adv. Haer. 5, 30, 3; Eusebio de Cesarea. HE3, 18, 1. 
opinión de que fue escrito en tiempo de la persecución de Nerón. Lo más aceptado en la actualidad es que procede del tiempo de Domiciano. Se suele decir habitualmente que este emperador fortaleció el culto imperial y exigió ser reconocido como Deus et Dominus, lo cual provocó un grave conflicto con los cristianos ${ }^{4}$. Sin embargo, últimamente se ha cuestionado esta opinión y con razones de peso42. El testimonio de algunos autores antiguos (Plinio el Joven, Suetonio, Dión Casio) se contradice con el de otros y parece que pintan peyorativamente a Domiciano para realzar a Trajano. Pero según las más recientes investigaciones Domiciano trató favorablemente a las regiones de Asia Menor y no acentuó las exigencias del culto imperial.

¿Cómo se explica entonces la descripción del Apopcalipsis? Esto ha dado pie a una importante discusión sobre la función social de este libro y, concretamente, sobre la relación que existe entre las imágenes simbólicas del texto y la situación histórica. L. Thompson, polemizando sobre todo con E. Schüssler Fiorenza, alerta contra el peligro de deducir del carácter crítico y dualista del texto una situación histórica de opresión y marginación. Este autor piensa, más bien, que el ámbito literario y el histórico guardan una notable independencia, de modo que el autor del Apocalipsis ha creado su propio mundo simbólico a partir de muchos factores, pero no presionado por unas circunstancias sociales particularmente graves. La tribulación es la suma referencia a Jesús crucificado, la hostilidad que encuentra en el mundo pagano, las eventuales acusaciones ante los tribunales y las diferencias con otras líneas cristianas más acomodaticias 43 .

Parece cierto que con Domiciano no se planteó una situación cualititativamente peor para las comunidades cristianas de Asia Menor. Pero una misma situación histórica es vivida de forma diferente por diversos grupos sociales. Se encuentran en el Nuevo Testamento comunidades cristianas que reaccionan de manera muy distinta ante los problemas planteados por la sociedad pagana y, concretamente, por la hostilidad de su ambiente.

Ante todo debe quedar claro una cosa: sin que haga falta imaginarnos una persecución en toda regla ni una proscripción expresa, la situación de los cristianos en Asia Menor, supuesta en la consulta que Plinio dirige a Trajano a comienzos del siglo II, es muy grave. Se les atribuían crímenes horribles, a veces bastaba la mera acusación de ser cristianos y de pertenecer a la comunidad para

41. W. H. C. Frend, op. cit., p. 158.

42. L. Thompson, The Book of Revelation: Apocalypse and Empire., New York and Oxford, 1990; Id., "A Sociological Analysis of Tribulation in the Apocalypse of John", Semeia 36 (1986), pp. 147-174.

43. L. Thompson, op. cit., p. 166: "La tribulación como un tema hiperbólico en el mundo literario de Jụan funciona no como un reflejo de las tensiones entre la fe y las realidades sociopolíticas, sino como expresión del conflicto que percibe entre los dos mundos". 
que pudiesen, incluso, ser conducidos a la muerte.

Hay un tipo de cristianismo, rellejado en el Apocalipsis, que vive esta situación como especialmente crítica y plantea una resistencia frontal ante su ambiente y ante las autoridades imperiales. Probablemente es el tipo de cristianismo de gente pobre, con pocas relaciones sociales y que experimenta una cierta marginación económica. La Iglesia de Laodicea, la más rica. es la más duramente tratada (3, 17-19). La radicalidad con que el Apocalipsis excluye la participación en los banqueles que seguían a los sacrificios (postura tan diferente a la de Pablo en la primera carta a los Corintios) indica que se trata de una comunidad cerrada sobre sí misma y poco atractiva para quienes cstaban acostumbrados a amplias relaciones sociales $(2,14,20)$.

El Apocalipsis juzga durísimamente el papel económico del imperio (capílulo 18) y describe la marginación económica de sus crislianos (13, 16-17). Pero esta actitud ante la sociedad romana y las autoridades imperiales no fue la única que existió en el cristianismo primitivo. Más aún, la postura reflejada en el Apocalipsis fue probablemente minoritaria. Quizá sea ésta una de las causas por las que costó tanto que este libro fuese reconocido como canónico por todas las iglesias.

En las cartas a las siete iglesias se polemiza con otras corrientes cristianas (la doctrina de Balaam, los nicolaitas, la doctrina de la proletisa Jezabel), a las que acusa de aceptar comer la carne sacrificada a los ídolos y de fornicar $(2,2.14$ 15.20). ¿De qué se trata? Probablemente son cristianos que. como san Pablo, saben que "el f́dolo no es nada" (1Cor 8,4$)$ y que, por tanto, no hay ningún problema en comer las carnes que proceden de los sacrilicios a ellos tributados. Esta es la opinión de Pablo, que la defendió frente a otros cristianos, a quienes consideraba "débiles" y que no aceptaban comer "idolotitos" en ninguna circunstancia. La acusación de "fornicar" recoge una vieja tradición boblica, que designaba así al culto a dioses extranjeros, y se refiere a la participación en en el culto imperial. Probablemente había cristianos conscientes del carácter formalista de muchas de las ceremonias de la religión oficial, que eran meros ritos sociales, y no implicaban una real confesión de fe religiosa y que, por tanto, en algunas circunstancias, no tenían inconveniente en participar en los cultos de su ciudad. El Apocalipsis es totalmente opuesto a esta actitud y es mucho más hostil respecto a la sociedad pagana en general y respecto a sus manilestaciones religiosas en particular. Esta tradición radical sería continuada más tarde por el montanismo con su orientación profética y en abierta ruptura ya con la gran Iglesia de cuño petrino-paulino

\subsubsection{Superación del afán de venganza y el amor a los enemigos}

El Apocalipsis nos obliga a plantearnos un problema de permanente actuali- 
dad: ¿el afán de revancha puede incubarse en el corazón del perseguido?; ¿el ansia de justicia puede llevar a legitimar la violencia? $Y$ es que este libro habla de la ira de Dios $(14,10.19 ; 15,1.7 ; 16,1.19 ; 19,15)$ y de la cólera del Cordero (6, 16-17) en términos muy duros. Las copas de la ira de Dios descargan sobre la lierra, castigando a la Bestia y a sus siervos en lo mismo que ellos han hecho: el mar $y$ todas las fuentes se convierten en sangre como venganza por toda la sangre inocente que ellos injustamente han derramado (16, 1-7).

No se puede evitar un cierto estremecimiento cuando se lee que quien haya adorado a la Bestia y haya aceptado su marca en la frente o en la mano "beberá del vino del furor de Dios, que ha sido derramado sin mezcla en la copa de su ira, y será atormentado con luego y azufre delante de los santos ángeles y delante del Cordero, y el humo de su tormento subirá por los siglos de los siglos" (14, 9-II). El rey mesías es un guerrero, "que viste un manto empapado en sangre". "de cuya boca sale una espada aguda para herir a las naciones" y que "pisa el lagar del vino del furor de la cólera de Dios todopoderoso" (19, 1115).

Estas imágenes pueden generar una enorme violencia, porque parece que anidan una gran sed de venganza44 y expresan una destrucción imaginativa del perseguidor. Más aún: scgún el Apocalipsis, la persecución es, en última instancia, obra de Satán (cfr. 12, 17) y, por tanto, es legítimo reaccionar con "odio santo". La tentación de la violencia es más peligrosa cuando se cree dirigida contra los enemigos de Dios.

Creo que no se comprende de verdad el Apocalipsis si no se comparte su profunda experiencia de la tribulación —opresión, marginación y persécucióna la vez que su anhelo de justicia. Podría resultar injusta y trivial una interpretación del Apocalipsis desde la comodidad de la vida académica o desde una lglesia poderosa y bien instalada. Pero también es verdad que las imágenes del Apocalipsis deben ser leídas y criticadas desde las palabras de Jesús de "amen a los enemigos y oren por los que les persiguen" (Mt 5, 44; Rom 12, 14-21; Lc 23, 34; Hech 7,60;1Cor 4, 12). Una autora sumamente crítica, que describe muy bien la situación social del Apocalipsis y su mensaje de esperanza, nos previene también contra las limitaciones y peligros de su lenguaje y de su misma visión teológica:

El Apocalipsis tiene el peligro de concebir el poder divino en los términos de la dominación romana como poder sobre y como poder opresor. Aunque el autor intenta transformar el lenguaje y las imágenes de la realeza y de la

44. J. Lichl, "Taxo or the Apocalyptic Doctrine of Vengeance", The Journal of Jewish Studies 12. 196I, pp, 95-105; A. J. COLLINS, "Persecution and Vengeance in the Book of Revelation", en D. Hellholm (ed.), Apocalypticism in the Mediterranean World and the Near East, Tübingen, 1983, pp. 729-749. 
dominación es dudoso que lo consiga para la mentalidad del lector de hoy ... La teología cristiana y la liturgia deben reemplazar estas simbolizaciones divinas expresadas en términos de poder imperial y belicismo destructivo con un lenguaje y unas metáforas para Dios y Cristo que alimenten la creatividad humana, la responsabilidad democrática y fomente la resistencia contra todos los poderes políticos que deshumanizan, destruyen y oprimen45.

Estas cautelas son muy pertinentes, porque al estudiar los inicios cristianos nos encontramos con una amarga paradoja y con una triste lección: una Iglesia que fue marginada y perseguida, muy pronto, cuando se convirtió en la garante de la ideología dominante, marginó y persiguió.

\section{Conclusiones}

Voy a recapitular las principales conclusiones del estudio realizado, relacionándolas con olros datos del Nuevo Testamento y presentándolas de manera que estimule la reflexión posterior.

1. La persecución se manifiesta de diversas formas en el cristianismo de los orígenes. Primeramente fue la consecuencia de un connicto intrajudío. Los seguidores de Jesús, el mesías crucificado, rompían la unidad religiosa básica de la familia judía. El conflicto pasaba a las sinagogas y al ambiente judío en general. Los cristianos podfan ser expulsados de las sinagogas e, incluso, conducidos a la muerte, como en los casos de Esteban, de Santiago el Zebedeo y de Sanliago el hermano del Señor.

Pronto los cristianos conocieron también tribulaciones y persecuciones en el imperio romano, en las que se mezclaban la animadversión de la sociedad paganа у la intervención de las autoridades. Se proferfan acusaciones gravísimas contra los cristianos, se veían con antipatía y desconfianza unas actitudes disidentes respecto a los valores dominantes; en cierto modo resultaban los "chivos expiatorios" de los problemas de aquella sociedad. Se los perseguía también "por el nombre", por el mero hecho de ser cristianos; probablemente el confesarse discípulos de un ajusticiado por el poder romano los haría incurrir en el delito de lesa majestad46.

También se veía, a veces, en las comunidades cristianas collegia peligrosas, que debfan ser prohibidas. Otras veces se los acusaba de ser ateos, por su exclusivismo religioso, en continuidad con el judío, pero sin gozar del estatuto de religión lícita y con el agravante, además, de ser un exclusivismo más ambi-

45. E. Schüssler Fiorenza, op. eit., pp. 123s.

46. J. Montserrat, El desafio cristiano: Las razones del perseguidor, Madrid, 1992, pp. 113-162. 
cioso porque no se circunscribía a los límites étnicos de un pueblo, molestaba a los dioses de la ciudad y podía provocar el desamparo religioso.

2. Hay una relación íntima entre la persecución y la vida de Jesús de Nazaret. En la medida en que la comunidad cristiana hace de la vida del crucificado (crucificado en nombre de Dios y porque ponía en peligro el orden, tanto del poder judío, como del romano) su punto de referencia no encuentra un ajuste cómodo en ninguna sociedad y fácilmente entra en conflicto con ella. El cristiano no puede extrañarse de la persecución y tiene que contar siempre con élla (Jn 15, 20; Mt 10, 24-25; IPd). La persecución puede revestir mil formas diferentes e, incluso, en la sociedad democrática tiene sus propias características.

Por eso, en la medida en que la Iglesia se fue ajustando y acomodando a la sociedad grecorromana existió la tendencia a diluir la referencia a la vida hisıorica de Jesús. Ignacio de Antioquía dice que los docetas niegan la verdad de la vida carnal de Crisıo y, por eso, son incapaces de seguirlo hasta el martirio (Tral 10; Esm II-III; IV, 2).

Los evangelios se escribieron, en buena medida, para reivindicar $-\mathrm{y}$ lo tienen que hacer polémicamente- la vida teı.estre del crucificado en una Iglesia, que imbuida de la luz pascual y preocupada por evitar conflictos, tiene la tendencia a olvidarla. Por eso, los evangelios sinópticos presentan la vida cristiana como el seguimiento de un Jesús perseguido y martirizado.

Cuando las primeras comunidades experimentaron la persecución volvieron los ojos a la vida de Jesús y redescubrieron su sentido. Esteban, el protomártir cristiano, muere fijando sus ojos en Jesús. La primera carta de Pedro relaciona continuamente los sufrimientos de los cristianos con los de Jesús, interpretados a la luz de los cantos del Siervo de Isaías. En el Apocalipsis de Juan Jesús es el testigo y el primogénito de los mártires $(1,5)$. En la Carta a los Hebreos se exhorta continuamente a la huponone y para ello se insta a poner los ojos en Jesús, "el que inicia y consuma la fe", el que aguantó la cruz (hupemeinen stauron) y el que aguantó la oposición de parte de los pecadores (hupomemenekota hupo ton amartolon eis eautou antilogian) (Heb 12, l-4).

3. La persecución y el martirio son vistos como la forma eminente de identificarse con Cristo. Esta es la manera específicamente cristiana de teologizar la persecución y el martirio (Heb 12, 1-4; 1Pd 2, 20-21; 4, 13: "alégrense en la medida en que participan de los padecimientos de Cristo"). Policarpo de Esmirna continúa este tema neotestamentario y exhorta a ser "imitadores de su resistencia en el sufrimiento, y si por causa de su nombre tenemos que sufrir, glorifiquémoslo" (VIII, 2).

4. Por ser lugar de singular identificación con Cristo, la persecución es también un lugar privilegiado de experiencia cristiana. 
Ante todo es una ocasión privilegiada de testimonio del evangelio (Mc 13,910). Contra lo que cabía esperar, las cadenas en que se ve Pablo y que parecían frenar su carrera misionera "han contribuido más bien al progreso del evangelio" (Fil I, 12-14). La alegría no nace sólo pensando en la recompensa futura, sino que brota paradójicamente en medio de la persecución por causa de Jesús. La persecución es también una experiencia de esperanza, porque el cristiano se siente sostenido por la promesa de Dios y por el testigo fiel.

El propio dolor nos hace más capaces de descubrir el dolor de los demás. El cristiano perseguido se siente solidario con todos sus hermanos perseguidos (IPd 5, 9). Pero el Apocalipsis, coherente con su visión universalista, amplía esta óptica: en medio del dolor y de la opresión los cristianos se sienten solidarios con rodos los oprimidos por el imperio romano. La persecución de los verdaderos discípulos de Jesús es inseparable de la sangre de todas las víclimas inocentes de la historia (Apoc 18.24).

5. Las persecuciones de los cristianos a lo largo de la historia han tenido funciones sociales muy distintas y requieren valoraciones teológicas diferenciadas. No es posible entrar ahora en esta problemática.

Pero hay una cosa clara: Ia Iglesia perseguida en el Nuevo Testamento no es una institución poderosa, no es aún ni siquiera una entidad claramente definida. La autoridad imperial probablemente no sabía muy bien si eran una secta judía o un nuevo y exıraño collegium.

Eran perseguidos "por el nombre", "a causa de Jesús". Los seguidores de un crucificado tenían que resultar peligrosos a los ojos del imperio. Esto es lo que vimos en el rescriplo de Trajano y continuó en el liempo posterior. Pero eran también acusados de mil cosas gravísimas (flagitia). Y es que eran unas comunidades minoritarias, pero innovadoras, socialmente peligrosas, al menos potencialmente, porque perturbaban el orden social patriarcal, legitimado religiosamente.

6. En el cristianismo primitivo hubo distintas actitudes a la hora de afrontar la persecución, de un modo paralelo a como hubo diferentes posturas a la hora de relacionarse con el mundo.

La primera carta de Pedro y el Apocalipsis, procedentes de un área geográfica muy próxima, reaccionaron de maneras muy diferentes ante dificultades muy similares. La primera carta de Pedro no renuncia a dialogar con el perseguidor, a exponer las propias razones y a hacerse entender, y no desespera de encarnarse como fe y como institución en la sociedad pagana. La Iglesia de la primera carta de Pedro reafirma fuertemente su identidad amenazada, pero no quiere convertirse en un ghetto cerrado y no renuncia a una dinámica de expansión. Para el Apocalipsis, el imperio es el poder de la Bestia, el mal absoluto, ante el que no cabe más que una resistencia sin cuartel. Por eso, la gran Iglesia tuvo dificulta- 
des para aceptar este libro en su canon.

Ante la persecución, la gran Iglesia navegó entre dos escollos que pretendía evitar. El primero eran los lapsi, los que ante la dificultad apostataban de la fe. De ahí la llamada a resistir, a mirar el ejemplo de Cristo y el recurso a otros motivos teológicos. El otro escollo era el de los mártires voluntarios, que buscaban provocar la persecución y su muerte; la gran Iglesia siempre condenó este fanalismo, que conducía a la claudicación de muchos cristianos y podía llevar a la desaparición de las comunidades o, al menos, al cierre de sus posibilidades misioneras y de expansión.

7. El lugar de la mayor cercanía de Dios es también el de la máxima tentación. Esto sucedía en la persecución, en que podía incubarse la destrucción imaginaria del perseguidor, el deseo de revancha y el odio, legitimado teológicamente, porque se ve en el perseguidor al enemigo mismo de Dios. En medio de la persecución y del martirio resuenan las palabras de Jesús: "amen a sus enemigos y oren por quienes les persiguen". El primer mártir cristiano, Esteban, muere, como Jesús, pidiendo el perdón para sus verdugos.

La referencia a Jesús introduce en medio de la persecución la fuerza para resistir al perseguidor y la fuerza para resistir también a la inercia humana de la venganza y del poder. No se resiste a base de fanatismo ni de interiorización de una lógica institucional. El seguidor de Jesús resiste por apertura al misterio de Dios y de su reino. 